\title{
Control of ornamental sunflower height with daminozide
}

\section{Controle do porte de girassol ornamental com daminozide}

\author{
Francine Lorena Cuquel ${ }^{1 *}$; Maria Carolina Sabbagh²; \\ Ana Cláudia Barneche de Oliveira ${ }^{3}$
}

\begin{abstract}
New sunflower (Helianthus annuus L.) cultivars with ornamental features were developed in South of Brazil by Empresa Brasileira de Pesquisa Agropecuária (EMBRAPA-CNPSoja). Despite its beauty, the hybrid 'BRS-Oasis' reaches over two meters height, with dimensions inadequate to an ornamental plant. The goal of this research was to decrease its height, without reducing stem and head diameter, to growth it as cut flower inside greenhouse or as potted plant. Daminozide, a growth retardant, was applied twice or three times, at concentrations of 4,000 mg.L. $\mathrm{L}^{-1} ; 6,000 \mathrm{mg} . \mathrm{L}^{-1}$; or $8,000 \mathrm{mgL}^{-1}$. An additional treatment by applying just water was used as a control. Height control, without decreasing stem and head diameters was obtained by applying Daminozide twice at $6,000 \mathrm{mg} \cdot \mathrm{L}^{-1}$ or Daminozide three times at 4,000 mg.L-1 Final plant height was adequate to growth 'BRS-Oasis' as a cut flower inside greenhouse, but not small enough to growth it as a potted plant.
\end{abstract}

Key words: Helianthus annuus, B-nine, plant growth regulator, growth retardant, floriculture

\section{Resumo}

Novas cultivares de girassol (Helianthus annuus L.) com características ornamentais foram desenvolvidas pela Empresa Brasileira de Pesquisa Agropecuária (EMBRAPA-CNPSoja). Embora apresente potencial ornamental, o hibrido 'BRS-Oasis' apresenta altura superior a dois metros, a qual não é adequada para cultivo como planta ornamental. O objetivo deste trabalho foi reduzir seu porte, sem reduzir os diâmetros da haste e da inflorescência, para cultivo como flor de corte em estufa e como planta envasada. Este regulador foi aplicado duas a três vezes durante o ciclo, nas concentrações de $4.000 \mathrm{mg} . \mathrm{L}^{-1}, 6.000 \mathrm{mg} . \mathrm{L}^{-1}$ ou $8.000 \mathrm{mgL}^{-1}$. Como controle foi utilizada a aplicação de água. A redução do porte, sem redução dos diâmetros da haste e da inflorescência, foi obtida aplicando-se Daminozide duas vezes na concentração de $6.000 \mathrm{mg} . \mathrm{L}^{-1}$ ou três vezes na concentração de $4.000 \mathrm{mg} . \mathrm{L}^{-1}$. A altura das plantas favoreceu o cultivo em estufa, entretanto o porte não foi reduzido o suficiente para cultivo em vaso.

Palavras-chave: Helianthus annuиs, B-nine, regulador de crescimento vegetal, inibidor de crescimento, floricultura

1 Ph.D., Professor, Universidade Federal do Paraná, Departamento de Fitotecnia e Fitossanitarismo. E-mail: francine@ufpr.br

2 MSc, Universidade Federal do Paraná. E-mail: carol.sabbagh@terra.com.br

3 Ph.D., Embrapa de Clima Temperado. E-mail: barneche@cpact.embrapa.br

* Autor para correspondência 


\section{Introduction}

Sunflower (Helianthus annuus) has been a popular ornamental plant in North America and Europe, grown for pot and cut flower purposes (WHIPKER; DASOJU, 1998; SCHOELLHORN; EMINO; ALVAREZ, 2003). It has recently acquired importance as ornamental plant in the Brazilian market (NEVES et al., 2005). The main sunflower cut flower cultivars growths worldwide are the 'Sunbright', 'Sunrich Lemon', 'Sunrich Orange', 'Soraya', and 'Moulin Rouge' (SCHOELLHORN; EMINO; ALVAREZ, 2003), and for potted purpose are 'Big Smile', 'Elf', 'Pacino', 'Sundance Kid', 'Sunspot', and 'Teddy Bear' (WHIPKER; DASOJU, 1998). Brazilian sunflower cultivars were developed by Empresa Brasileira de Pesquisa Agropecuária (EMBRAPA-CNPSoja) with ornamental charactheristics (CASTIGLIONI; LEITE; OLIVEIRA, 1997).

Plant height is an important feature to ornamental plants. Sunflowers plants shorter than 2 meters are easier to growth as cut flowers inside greenhouse. 'Sun', from Sakata Seed, is the most important sunflower cultivar growth as cut flower in Brazil, reaching the final plant height of $1.5 \mathrm{~m}$ (BONACIN; RODRIGUES; MATTIUZ, 2006). The maximum height for potted plants is 1.5 times the pot height (MOTOS; OLIVEIRA, 1998). Despite its beauty, the hybrid 'BRS-Oasis', developed by EMBRAPACNPSoja (CASTIGLIONI; LEITE; OLIVEIRA, 1997), reaches over two meters, with dimensions inadequate to growth it as cut flower inside greenhouse or as potted plant. Even, the sunflower cultivation protocol is not well established (GIUFFRIDA; CASSANITI; LEONARDI, 2009).

Ornamental plant size control by reducing the unwanted longitudinal growth has been achieved by applying PGR, inhibitors of gibberellin synthesis, such as Sumagic (Uniconazole), Bonzi (Paclobutrazol), and B-Nine (Daminozide) (LATIMER, 2001; LATIMER, 2004; WHIPKER et al., 2004).
Daminozide concentrations recommended to several ornamental plants are from 2,000 mg.L $\mathrm{L}^{-1}$ to 7,000 mg. $\mathrm{L}^{-1}$ (LATIMER, 2004). PGR applied on sunflower by drench usually are more effective than foliar spray without the negative effects on sunflower quality (WHIPKER et al., 2004). Foliar sprays of Sumagic (Uniconazole), between 16 and $32 \mathrm{mg} . \mathrm{L}^{-1}$, or with B-Nine (Daminozide), between 4,000 and 8,000 mg. $\mathrm{L}^{-1}$, reduced the sunflower height (WHIPKER; DASOJU, 1998; WHIPKER; McCALL 2000; PALLEZ; DOLE; WHIPKER, 2002; WHIPKER et al., 2004). One to four PGR applications are recommended during the plant growth (LATIMER, 2004). The best time to apply PGR to reduce the sunflower growth is not clear yet. Pallez, Dole and Whipker (2002) obtained good results by applying PGR 14 day from sowing.

The interaction effects between PGR and cultivars on sunflowers quality parameters are known (WHIPKER; McCALL 2000; WANDERLEY; REZENDE; ANDRADE, 2007; GIUFFRIDA; CASSANITI; LEONARDI, 2009). PGR might reduced drastically the sunflower head diameter (WHIPKER; McCALL 2000; WANDERLEY; REZENDE; ANDRADE, 2007).

The goal of this research was to decrease hybrid 'BRS-Oasis' height, without reducing stem and head diameter, to growth it as cut flower inside greenhouse or as potted plant.

\section{Materials and Methods}

The Helianthus annuus cultivar evaluated in this research was the hybrid 'BRS-Oasis', developed by Empresa Brasileira de Pesquisa Agropecuária (EMBRAPA-CNPSoja), with brownish central florets and yellow ray florets. It was carried out during the spring at latitude $25^{\circ} 37^{\prime} 32^{\prime \prime} \mathrm{S}$, longitude $49^{\circ} 15^{\prime} 29^{\prime \prime} \mathrm{W}$ and altitude of $910 \mathrm{~m}$ (PR, Brazil), where the environmental temperatures range from $11.2^{\circ} \mathrm{C}$ and $20.2^{\circ} \mathrm{C}$, and relative humidity from $62.5 \%$ and $70.4 \%$. 
Foliar spray of Daminozide (B-Nine 850

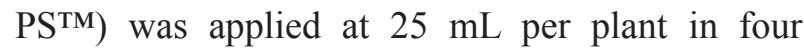
concentrations $\left(0 ; 4,000 ; 6,000 ; 8,000 \mathrm{mg} \mathrm{L}^{-1}\right)$, number of applications ( 2 or 3 times, with the same concentration). Two foliar sprays were applied at 15 and 30 days after sowing and three sprays were applied at 15, 30 and 45 days after sowing. Experimental field design was factorial (4 concentrations x 2 number of applications) in randomized complete blocks, containing 4 blocks, and 10 plants per block. All plants were evaluated 93 days after sowing, when $50 \%$ of the plants showed the ray florets completely expanded and all the disc florets visible, corresponding to R5.5 phenological scale (WANDERLEY; REZENDE; ANDRADE, 2007). Features evaluated were plant height (measured from the soil surface to the upper inflorescence), stem diameter (measured with a digital pachymeter $50 \mathrm{~cm}$ below the inflorescence) and head diameter (measured with a digital pachymeter). Data were submitted to variance analysis (F test) and the means were compared by the Tukey Test at the level of 5\% of probability.

\section{Results and Discussion}

Results obtained demonstrated that the best concentration to reduce the plant height depends simultaneously on the concentration and the number of applications (Table 1). Higher concentration was necessary to control sunflower height when Daminozide was twice applied at 15 and 30 days after sowing $\left(6,000 \mathrm{mg} . \mathrm{L}^{-1}\right)$ than when it was applied three times 15, 30 and 45 days after sowing $\left(4,000 \mathrm{mg} \cdot \mathrm{L}^{-1}\right)$ (Table 1). Similar results were also observed with the sunflower cultivar 'Pacino' with height control by applying Daminozide 4,000 $\mathrm{mg} . \mathrm{L}^{-1}$ (WATANABE, 2007). It is possible to suppose that Daminozide applied twice at 4,000 $\mathrm{mg} . \mathrm{L}^{-1}$ presented degradation, having short-term effect and short activity, as was postulated by Latimer (2001). It might have stopped inhibiting gibberellin synthesis, and the third application helped to mediate height growth control. At 6,000 mg.L L $^{-1}$, although Daminozide degradation process might have occurred, some residual product might have remained inhibiting gibberellin synthesis, and in consequence controlling the unwanted longitudinal growth.

Table 1. Features of the ornamental sunflower hybrid 'BRS-Oasis', after applying Daminozide by two (15 and 30 days after sowing) or three times (15, 30 and 45 days after sowing) (PR, Brazil).

\begin{tabular}{|c|c|c|c|c|c|c|}
\hline & \multicolumn{2}{|c|}{ Plant height (m) } & \multicolumn{2}{|c|}{ Stem diameter $(\mathrm{cm})$} & \multicolumn{2}{|c|}{ Head diameter $(\mathrm{cm})$} \\
\hline $\begin{array}{l}\text { Concentration/ } \\
\text { Times }\end{array}$ & 2 & 3 & 2 & 3 & 2 & 3 \\
\hline Control & $2.05 \mathrm{aA}$ & $1.99 \mathrm{aA}$ & $1.1797 \mathrm{aA}$ & $1.1760 \mathrm{aA}$ & $8.252 \mathrm{aA}$ & $8.336 \mathrm{aA}$ \\
\hline $4000 \mathrm{mg} . \mathrm{L}^{-1}$ & $2.04 \mathrm{aA}$ & $1.81 \mathrm{bB}$ & $1.1992 \mathrm{aA}$ & $1.1600 \mathrm{aA}$ & $8.395 \mathrm{aA}$ & $8.001 \mathrm{aA}$ \\
\hline $6000 \mathrm{mg} . \mathrm{L}^{-1}$ & $1.86 \mathrm{aB}$ & $1.94 \mathrm{aAB}$ & $1.1940 \mathrm{aA}$ & $1.1640 \mathrm{aA}$ & $8.177 \mathrm{aA}$ & $8.003 \mathrm{aA}$ \\
\hline 8000 mg.L ${ }^{-1}$ & $2.00 \mathrm{aA}$ & $1.94 \mathrm{aAB}$ & $1.1820 \mathrm{aA}$ & $1.1427 \mathrm{aA}$ & $8.059 \mathrm{aA}$ & $8.248 \mathrm{aA}$ \\
\hline
\end{tabular}

Means followed by the same capital letter in column and the same small letter in the line don't differ statistically at the $5 \%$ level of probability by Tukey Test.

Daminozide at 6,000 mg.L $\mathrm{L}^{-1}$ reduced sunflower height $9.26 \%$, and at 4,000 $\mathrm{mg} \cdot \mathrm{L}^{-1}$ reduced it 9.04\%. Positive effects of Daminozide in other sunflower cultivars were previously reported by several authors (PALLEZ; DOLE; WHIPKER, 2002; WHIPKER et al., 2004; BONACIN; RODRIGUES; MATTIUZ, 2006; WATANABE,
2007; GIUFFRIDA; CASSANITI; LEONARDI, 2009), with the efficiency depending on the cultivar and concentration applied.

The smallest sunflower plants produced were an average $1.86 \mathrm{~m}$ and $1.81 \mathrm{~m}$ tall, respectively to Daminozide applied two and three times (Table 1). This plant size can help producing plants inside 
greenhouse. But, that is not adequate to produce potted plants, because sunflower pots usually are 11 to $13 \mathrm{~cm}$ tall, what means that the 'BRS-Oasis' plants could be the maximum of $19.5 \mathrm{~cm}$ tall, 1.5 times the pot tall (MOTOS; OLIVEIRA, 1998). Similar results were observed by Bonacin, Rodrigues and Mattiuz (2006), which observed that sunflower (cultivars 'Sunbeam', 'Sunbright' and 'Sunbright Supreme') height was reduced by applying Daminozide, but the final height obtained by them was not small enough to potted plant growth. They attributed it to have sprayed Daminozide just once, and it was applied latter than it was done in this research (25 days after sowing, plants in average $21.45 \mathrm{~cm}$ tall). Results obtained here show that even when Daminozide was applied previously, and three times, it did not reduce the plant height as much as it was necessary for potted plant growing. Wanderley, Rezende and Andrade (2007) applying Paclobutrazol also in 'BRS-Oasis' obtained plant 1.40m tall (18\% shorter than non-treated plants), with the head diameter $10 \%$ smaller. So it is possible to suggest that to growth 'BRS-Oasis' as potted plant it is previously necessary to invest more efforts in plant breeding to reduce height without reducing the head diameter.

Daminozide from 4,000 to $8,000 \mathrm{mg} . \mathrm{L}^{-1} \mathrm{did}$ not decrease the 'BRS-Oasis' head diameter (Table 1), attending the consumer preference of big sunflower inflorescences for ornamental purpose. Different results were observed by Bonacin, Rodrigues and Mattiuz (2006), who observed that Daminozide decreased the sunflower head diameter (cultivars 'Sunbeam', 'Sunbright', and 'Sunbright Supreme'). Wanderley, Rezende and Andrade (2009), spraying Paclobutrazol (from 0.5 to 6.0 mg.L ${ }^{-1}$ ) on 'BRSOasis', observed that the head diameter was greatly affected, decreasing from 10 to $70 \%$, depending on the concentration sprayed. It is clear that the PGR effect over the sunflower quality pattern depends on the cultivar and PGR active ingredient applied.

Daminozide also did not affect the steam diameter (Table 1). These results were favourable taking into account that cut flower senescence and wilting can be associated with less water uptake by the stems (CARNEIRO et al., 2002), and fine stems are likely to be less long-lived compromising the sustenance of the inflorescences (NARDI et al., 2001).

\section{Conclusions}

Sunflower plant size cultivar 'BRS-Oasis' was reduced by applying Daminozide twice at 6,000 mg. $L^{-1}(9.26 \%)$ or Daminozide three times at 4,000 mg.L.' ${ }^{-1}(9.04 \%)$.

Final plant height was adequate to growth 'BRSOasis' as a cut flower inside greenhouse, but not small enough to growth it as a potted plant.

\section{References}

BONACIN, G. A.; RODRIGUES, T. de J. D.; MATTIUZ, C. F. M. Aplicação de retardadores de crescimento em híbridos de girassol ornamental. Revista Brasileira de Horticultura Ornamental, Campinas, v. 12, n. 1, p. 3742, 2006.

CARNEIRO, T. F; GIUFFRIDA, F.; CASSANITI, C.; LEONARDI, C. Influência da sacarose e do corte da base da haste na longevidade de inflorescências de Zinnia elegans. Pesquisa Agropecuária Brasileira, Brasília, v. 37, n. 8, p. 1065-1070, 2002.

CASTIGLIONI, V. B. R.; LEITE, R. M. V. B. C.; OLIVEIRA, M. F. Girassol Embrapa 122 - V2000. Londrina: EMBRAPA, CNPSo, 1997. 6 p. 1 Folder.

GIUFFRIDA, F.; CASSANITI, C.; LEONARDI, C. Effects of cultivation practices on sunflower production as cut flower, Acta Horticulturae, Leuven, v. 807, n. 2, p. 699-704, 2009.

LATIMER, J. G. Selecting and using plant growth regulators on floricultural crops. Virginia Cooperative Extension, Blacksburg, v. 430, n. 1, p. 1-5, 2001.

. Trends and uses of plant growth regulators on herbaceous perennials. Plant Growth Regulation Society of America Quartely, Alabama, v. 31, n. 3, p. 1-4, 2004.

MOTOS, J.; OLIVEIRA, M. J. G. Produção de crisântemos em vaso. Holambra, Flortec, 1998. 34 p. 
NARDI, C.; BELLÉ, R. A.; SCHMIDT, C. M.; TOLEDO, K. A. Qualidade de crisântemo (Dendranthema grandiflora Tzevelev.) cv. Snowdon em diferentes populações e épocas de plantio. Ciência Rural, Santa Maria, v. 31, n. 6, p. 957-961 2001.

NEVES, M. B.; BUZETTI, S.; CASTILHO, R. M. M. de; BOARO, C. S. F. Desenvolvimento de plantas de girassol ornamental (Helianthus annuus L.) em vasos, em dois substratos com solução nutritiva e em solo, Cientifica, Jaboticabal, v. 33, n. 2, p. 127-133, 2005.

PAlleZ, L. C.; DOLE, J. M.; WHIPKER, B. E. Production and postproduction studies with potted sunflowers, HortTechnology, Alexandria, v. 12, n. 2, p. 206-210, 2002.

SCHOELlHORN, R.; EMINO, E.; ALVAREZ, E. Specialty cut flower production guides for Florida: sunflower. Gainesville: University of Florida, IFAS Extension, 2003. 3 p.

WANDERLEY, C. S.; REZENDE, R.; ANDRADE, C. A. B. Efeito de Paclobutrazol como regulador de crescimento e produção de flores de girassol em cultivo hidropônico. Ciência e Agrotecnologia, Lavras, v. 31, n. 6, p. 1672-1678, 2007.

WATANABE, A. A. Desenvolvimento de plantas de girassol (Helianthus annuus l. cv. Pacino) com variação de nutrientes na solução nutritiva e aplicação de Daminozide. 2007. Dissertação (Mestrado em Botânica) - Instituto de Biociências. Universidade Estadual Paulista Júlio de Mesquita Filho, Botucatu.

WHIPKER, B. E.; DASOJU, S. Potted sunflower growth and flowering responses to foliar applications of diaminozide, paclobutrazol e uniconazole. HortTechnology, Alexandria, v. 8, n. 1, p. 86-88, 1998.

WHIPKER, B. E.; McCALL, I. Response of potted sunflower cultivars to daminozide foliar sprays and paclobutrazol drenches. HortTechnology, Alexandria, v. 10, n. 1, p. 209-211, 2000.

WHIPKER, B. E.; McCALL, I.; GIBSON, J. L.; CAVINS, T. J. Flurprimidol foliar sprays and substrate drenches control growth of 'Pacino' pot sunflowers. HortTechnology, Alexandria, v. 14, n. 3, p. 411-414, 2004. 
